By R. E. BUCHANAN

\title{
The Development and Function of a Research Library, I922/46
}

$\mathrm{T}$ HE PRESENT PAPER is an attempt on the part of one who has long played the role of bystander and friend to make some observations relative to the development of a research library on the campus of a technical institution. This development was largely the result of the efforts of one Charles Harvey Brown who came to Iowa State College as librarian in I922. The library which he then headed was mediocre. In less than a quarter of a century he built it into an outstanding service and research organization.

A satisfactorily functioning research library must contain the material most likely to be needed by the researchers, it should render prompt and efficient service, it should be suitably housed, and it must have a clientele eager to press the use of its facilities to the limit. The central figure largely determining the adequacy of these functionings is the librarian. C. H. Brown was well equipped to do a good job. In addition to other library experience, he had worked under the able leadership of C. W. Andrews in the John Crerar Library of Chicago, an outstanding scientific and technical library, one which makes a special effort to supply the needs of those interested in or engaged in research.

What did Brown find in 1922? The book collections numbered ninety thousand volumes. Fortunately since the founding of the library there had been some faculty men who took a keen interest in it and in its purchases. Men such as Bessey, Osborn, Franklin, and Pammel insisted from the beginning that there be subscriptions to the leading scientific journals of special interest and that a good deal of emphasis be laid upon foreign material. As a result, there were many valuable sets complete from Volume I. But this competence was true in only a few fields. Many of the scientific and technical journals were lacking in areas which Brown had the foresight to see would become highly significant in the future development of the institution. At the beginning of his librarianship he had primarily to serve the needs of the graduate school and two active research institutes, the agricultural experiment station and the engineering experiment station. During his incumbency there were added the veterinary research institute, the industrial science research institute, and the atomic research institute.

Dr. Brown seems to know almost instinctively the fields in which a technical institution such as Iowa State College would develop its research program. He was able to concentrate on purchases, today wholly unobtainable, that have proved invaluable. For example, with the passage of the prohibition amendment there were dispersals of library holdings of institutions related to the alcoholic beverage industries. Dr. Brown picked up sets of all the available 
journals relating to zymology and fermentation technology generally, until the library had perhaps the best collection of periodicals in these fields in the country. His wisdom was shown when during World War I technical libraries all over the United States came to him for assistance and for loans.

On his arrival on the campus, Dr. Brown found a library inadequately housed and particularly difficult of administration because the library's collections in agriculture, veterinary medicine, chemistry, botany, and engineering were housed apart from the central library. The situation was distressing not only to the librarian, but to members of the staff, including the writer. The latter found that material needed for carrying on research in bacteriology was housed in six different departmental libraries. Brown brought them together.

The staff of the library in 1922 was inadequate from the standpoint both of numbers and of training. Reorganization was prompt and efficient. Brown's ability to select competent appointees accounts for much of his success.

Dr. Brown took a personal interest in training the faculty of the institution in the use of a library. When he made facilities available, he expected them to be used. $\mathrm{He}$ made it quite clear in faculty meetings that not only did the faculty have the right and privilege of judging the adequacy and promptness of the services of the library, but that he had as librarian the responsibility of evaluating the usefulness of research men and faculty members generally on the basis of the use made of the library by them. And when criticism came from individuals whom he regarded as relatively incompetent on the basis of his library standards, he did not hesitate to lay down the law.

And now after the passage of a quarter of a century what progress has been made in the development of a satisfactory research library?

\section{Increase in Collection}

The book collections number more than fourfold those of 1922, about 370,000 volumes. Careful buying, persistent searching, European purchasing trips, have brought together an unusual collection of reference material. Compilations of pertinent data by the Association of Research Libraries indicate that in composite rankings the Iowa State College Library, in the fields covered by the program of the graduate college, ranks fifth among the research libraries of the United States. Particularly strong collections are held in the fields of chemistry, botany, physics, and mathematics.

It was recognized from the outset that a technical and scientific institution required a specialized library, and all efforts were focused on securing material in the somewhat restricted fields. It was unnecessary to purchase in areas such as dentistry, law, belles-lettres, or the humanities. Even in pertinent fields, some degree of specialization was observed. For example, the library entered into a cooperative understanding with the librarians of the University of Iowa and the University of Minnesota concerning fields of specialization. This permitted the Iowa State College Library to concentrate its buying power in the areas in which teaching and research were most emphasized and to build an adequate interlibrary loan system.

Dr. Brown and his library committee and many members of the faculty worked very closely together in building the collection. $\mathrm{He}$ was always anxious for suggestions as to fields about to develop for which plans should be made. He built a great collection because he found out what would be 
useful and hunted for it. He was glad to be told of the library defects and he enjoyed correcting them.

A competent and adequate library staff means prompt and satisfactory service. Books and references should be available quickly and with a minimum of inconvenience to the worker. The library was always complimented by requests for assistance. Members of the library staff participated directly and with credit in the preparation of scholarly bibliographies. Then, too, Brown believed in having some considerable degree of specialization on the part of members of his staff: individuals were sought and secured who were familiar with such fields as chemistry, sociology, or veterinary medicine. Ability to work in foreign language literature was also regarded as a staff asset; before World War II the institutional research staff could receive expert assistance in literature published in French, German, the several Scandinavian languages, Russian, Bulgarian, Spanish, Italian, Greek, and Latin. Such assistance is greatly appreciated.

\section{Centralized System}

Plans for a new building to house the library were well under way when Dr. Brown became librarian; he was able, however, to influence materially its functional design. $\mathrm{He}$ insisted that in an institution that needed to husband carefully its library budget, there could be no adequate excuse for the large number of small libraries on the campus; better service to all could be secured by centralization. Five years after the opening of the new building, the working capacity of the stacks was exhausted; the rapid growth of the student body, the graduate school, the activities of the several research institutes and the staff quickly overtaxed many of the facilities, including the loan desk, seminar rooms, cubicles for graduate students and staff, and the cataloging department. Plans for extensive additions have necessarily been deferred as to execution until the building situation is easier. Temporary and much-needed relief was secured by the erection of a large steel warehouse-type structure in which are stored those sets and series less commonly called for. However, even the books from this separate building are promptly delivered to reading room or laboratory.

Dr. Brown believes wholeheartedly that a library should give prompt, courteous, and efficient service. He succeeded in making his library outstanding in these particulars. He wanted to decrease the time between the request for a book and the time of delivery, whether to the loan desk or to the office of a research laboratory. The service is not to stop there; it should include the skilful use of skilled reference librarians and the interest of the staff in tracing down obscure references. The usual graduate student unfortunately does not know many of the techniques in getting at the resources of the library, the numerous indices and bibliographies and abstract journals and special aids; a prime objective of the library is to get him quickly into contact with the literature of his field. A course in the bibliography of science was started in 1924. The course was designed to give graduate students experience in the use of bibliographies in their major and allied fields. Five graduate students elected this course in 1924 ; in 194647 over 150 graduate students registered for the course.

Our librarian is an honored and valued member of the graduate faculty. $\mathrm{He}$ has always bluntly but effectively criticized those departments and those departmental staffs that he felt were not making the most of their opportunities in the development 
of their graduate programs. His criteria of efficiency? There were two, the use made of the library by the departmental staff and students, and the quality of the theses deposited with the library, where they are carefully collated. Woe to the graduate student whose citations did not meet reasonable standards of excellence; and the staff member with whom the student did his thesis problem by no means escaped unscathed. Brown believes in and insists on the use of good English and on good organization of material. Did he go beyond the conventional duties of a librarian in these matters? Perhaps (but we won't admit it). We all like him for it.

Years ago Dr. Brown assumed for the library the task of utilizing the great numbers of publications from the various research agencies of the institution for exchange for similar publications from other institutions. He used this exchange device most effectively in securing material from all over the world.

Another labor of love has been the annual carefully compiled list of publications of the members of the staff.

Here are some of the special services our librarian provided in the library. In several cases he pioneered in their development among the libraries of this country.

I. Prompt and accurate service from stacks.

2. Statement to client as to exact reason why a book could not be supplied.

3. Messenger service for delivery and collection of books and periodicals from the offices of members of the college staff.

4. Development of prompt and adequate training of graduate students in the efficient use of library resources.
5. Courteous treatment of all readers.

6. Stress on service to all, undergraduate and graduate student and faculty, with an earnest effort to render special service where needed.

7. Recall of books when needed by other readers after a reasonable period of time.

Dr. Brown's active and aggressive work in the Association of Research Libraries led to several distinct advantages to the Iowa State College. Particularly helpful were his studies on preparation of lists of the most-cited periodicals. Such lists assisted the library:

I. To develop high priority ratings in essential subject matter fields for publications being purchased for U.S. libraries by the cooperative purchasing commission of the $\mathrm{Li}$ brary of Congress.

2. To attain better and more general recognition of the relative importance of collections of scientific and technical periodicals in the physical and biological sciences and book collections in the fields of the humanities, with consequent gain in the relative ratings of libraries such as that of Iowa State within the Association of Research Libraries.

Dr. Brown has been and is a member of numerous boards and committees of library associations: his activities have been local, national, and international. But in all his labors he has sought the development of that which was dear to his heart, the Iowa State College Library. He has proved himself to be a master at this task. He has earned for himself a place in that niche of fame described by Pliny:

Equidem ita sentio, peculiarem in studiis causam eorum esse qui difficultatibus victis utilitatem iuvandi praetulerunt gratiae placendi. 